\title{
PECULIARITIES OF MORPHOGENESIS OF UNIVERSAL HEMATOPOESIS AND IMMUNE PROTECTION IN FETUSES OF DOMESTIC PIG
}

\author{
P. Gavrilin, A. Oliyar, O. Myrnyi \\ oliiar.a.v@dsau.dp.ua
}

Dnipropetrovsk State Agrarian and Economic University,

25 Voroshylova, str., Dnipro 49600, Ukraine

It was established that prenatal skeletal ontogeny in domestic pigs is presented in two forms: structural and functional bone marrow osteoblast (bone formation) and hematopoietic (blood-forming) development and structural and functional transformation that is taking place in parallel, different speeds towards vectors which are in particular histogram and cytoarchitectonic in different zonal centers of ossification of the skeleton in the fetus. The main structural components of the bone marrow domestic pig fetal within cells of the bone marrow centers of ossification of the bone shaft located in some models directly related to the dynamics of quantitative tissue components.

In the fetuses of especially late in the fetal period of ontogenesis (from 3 months) against the background of almost complete disappearance of hematopoietic centers in the liver begin to form as an unfinished structure segments with indistinct borders and lobules, although expressive (Relief) with outline radial hepatocyte structure and separated from each other with a thick connective tissue.

The basic characteristics, structural and functional bone marrow of the domestic pig fetuses are: localization in the spongy bone, leading to skeletal ossification centers, clearly marked morphological heterogeneity of the osteogenic distribution peripheral and central - hematopoietic form. Zonal structure of hematopoietic marrow gives the presence of islets and islet diffuse, with topographically distinct sections.

Keywords: LIVER, BONE MARROW, FETAL DOMESTIC PIG, OSSIFICATION CENTERS

\section{ОСОБЛИВОСТІ МОРФОГЕНЕЗУ ОРГАНІВ УНІВЕРСАЛЬНОГО КРОВОТВОРЕННЯ ТА ІМУННОГО ЗАХИСТУ У ПЛОДІВ СВИНІ СВІЙСЬКОЇ}

\author{
П. М. Гаврилін, А. В. Оліяр, О. М. Мирний \\ oliiar.a.v@dsau.dp.ua
}

Дніпропетровський державний аграрно-економічний університет,

вул. Ворошилова, 25, м. Дніпро, 49600, Україна

Встановлено, щзо в пренатальному періоді онтогенезу у скелеті свині свійської присутні дві структурно-функиіональні форми кісткового мозку: остеобластична (кісткоутворювальна) та гемопоетична (кровотворна), розвиток і структурно-функиіональна трансформація яких проходить паралельно, з різною швидкістю та векторами напрямку, щьо в сукупності проявляється особливостями його зональної гісто- та циитоархітектоніки в різних осередках окостеніння скелета плодів. Основні структурні компоненти кісткового мозку у плодів свині свійської в мељсах кістковомозкових вічок осередків окостеніння кісткових органів розташовуються у певній закономірності та безпосередньо взаємопов'язані з кількісною динамікою тканинних компонентів.

У плодів свині свійської, особливо наприкінці плідного періоду онтогенезу (починаючи з 3-місячного віку), на тлі майже повного зникнення центтів гемопоезу, в печінці починають формуватися як часточки незавершеної структури з нечіткими межсами, так і часточки, щз мають виразні (рельєфні) контури радіальних балок гепаточитів і відокремлені одна від одної потовщеною сполучною тканиною.

Основними структурно-функціональними характеристиками кісткового мозку плодів свині свійської є: локалізація в губчастій кістковій речовині основних осередків окостеніння скелета, чітко виражена морфологічна гетерогенність з розподілом на периферичну остеогенну та центральну - гемопоетичну форми, зональна структура кровотворного кісткового мозку з наявністю острівиевих та дифузноострівиевих, топографічно відокремлених ділянок.

Ключові слова: ПЕЧІНКА, КІСТКОВИЙ МОЗОК, ПЛОДИ СВИНІ СВІЙСЬКОЇ, ОСЕРЕДКИ ОКОСТЕНІННЯ 


\title{
ОСОБЕННОСТИ МОРФОГЕНЕЗА ОРГАНОВ УНИВЕРСАЛЬНОГО КРОВЕТВОРЕНИЯ И ИММУННОЙ ЗАЩИТЫ У ПЛОДОВ СВИНЬИ ДОМАШНЕЙ
}

\author{
П. Н. Гаврилин, А. В. Олияр, А. Н. Мирный \\ oliiar.a.v@dsau.dp.ua
}

Днепропетровский государственный аграрно-економический университет, ул. Ворошилова, 25, г. Днепр, 49600, Украина

Установлено, что в пренатальном периоде онтогенеза в скелете свиньи домашней присутствуют две структурно-функциональные формы костного мозга: остеобластическая (костеобразующая) и гемопоетическая (кроветворная), развитие и структурно-функциональная трансформация которых проходит параллельно, с разной скоростью и векторами направления, что в совокупности проявляется особенностями его зональной гисто- и циттоархитектоники в разных очагах окостенения скелета плодов. Основные структурные компоненты костного мозга у плодов свиньи домашней в пределах костномозговых ячеек очагов окостенения костных органов располагаются в определенной закономерности и непосредственно взаимосвязаны с количественной динамикой тканевых компонентов.

У плодов свиньи домашней, особенно в коние плодного периода онтогенеза (начиная с 3-месячного возраста), на фоне почти полного исчезновения цеентров гемопоеза, в печени начинают формироваться как дольки незавершенной структуры с нечеткими границами, так и дольки, имеющие выразительные (рельефнье) контуры радиальных балок гепаточитов и отделенные друг от друга утолщенной соединительной тканью.

Основными структурно-функичональными характеристиками костного мозга плодов свиньи домашней являются: локализачия в губчатом костном веществе основных очагов окостенения скелета, четко выраженная морфологическая гетерогенность с распределением на периферическую остеогенную и центральную - гемопоэтическую формы, зональная структура кроветворного костного мозга с наличием островковых и диффузно-островковых, топографически обособленных участков.

\section{КлючевЫе слова: ПЕЧЕНЬ, КОСТНЫЙ МОЗГ, ПЛОДЫ СВИНЬИ ДОМАШНЕЙ, ОЧА- ГИ ОКОСТЕНЕНИЯ}

The structural-functional organization of the blood formation and immune protection by mammals can be described with different kinds of cells which show the degree of their functional activity $[1,5,6]$.

The quantitative and qualitative changes of the hemopoietic cell and immunocompetent cell inside the liver and the centers of the calcification of the bone-cutting organs of the skeleton by mammals during antenatal life of ontogenesis are the clear reflection of the regularities of the changes from hepato-myeloid blood formation to the myeloid one with further formation of two main functions of the bone marrow - osteogenic and blood-making in the conditions of the phisiological limited biomechanical stress on the osteal system $[4,7,9]$.

The structural-functional difference of the bone-marrow on the different stages of its evolution, especially during the formation and increase of the marrowy stage of the multi-function of the hemogenesis together with weakening of the liver- stage that needs to be more reconsidered, especially on the early stages of the antenatal life of the ontogenesis $[1,2,5,10]$.

Research purposes. To define the morphofunctional laws of the histogenesis and cytogenesis of liver and bone marrow of an embryo of Sus scrofa domestica (a swine).

\section{Material and methods}

The work was pursued on the basis of the laboratory of the histologic anatomy, pathmorphology and immunocytochemistry of the Research and Development Centre of biosafety and ecological control of the resources of Dnipropetrovsk Agricultural State University. As the research object an embryo of the Ukrainian Large White breed of domestic pig was considered.

The material from liver, bones of the axial skeleton (a mandibular bone, the $5^{\text {th }}$ thoracal backbone, the $5^{\text {th }}$ costal bone, breast bone, $1^{\text {st }}$ and $5^{\text {th }}$ caudal spines) of the skeleton of the extremities 
(humeral bone, femoral bone (astragalus), shin bones and the bones of the foot) of embryos of 1.5-, 2-, 2.5-, 3-, 3.5- and 4 months was used.

The paraffin sections were produced for coloration with hematoxylin and bromeosin, azure II-eosin and silver impregnation.

The total paraffin sections with their thickness of 5-10 mkm were prepared with the help of a sledge MS- 2 and rotary MPS- 2 microtomes. The research of the histospecimens was conducted by means of microscopes of biological stereometric MBS-10, Olimpus $C H 20$ and $C X 41$. The relative area was defined of the material components in the centre of ossification (cartilaginous tissue, osseous tissue and bone marrow) cellular components of the bone marrow with the help of the microscope Olimpus $\mathrm{CH} 20$ (ocular lens 10x, field lens $40 \mathrm{x} / 0.65$ ) in the main and additional centers of the ossification, using the method of 'a precision calculation' with the help of a standard eyepiece graticule by Avtandilov. The cellular composition of the bone marrow (the medullary image) was analyzed apart in the areas of the primary and secondary cancellous tissue of the main (diaphyseal) and additional (epiphyseal, apophyseal) centres of the ossification. The zone of the secondary cancellous tissue on diaphyseal centres of the ossification was additionally divided into proximal, distal and middle fields.

\section{Results and discussion}

The histological studies show that the liver in embryos of Sus scrofa domestica that are 1.5 months old is submitted by stroma and parenchyma (the myeloid tissue). At the beginning of the fetal period of ontogenesis, the connective tissue of stroma in the liver was sufficiently great and it was $6.43 \pm 0.93 \%$. The connective tissue of stroma in the liver increased by 5.0, 8.45 and $7.12 \%$ in the fetuses of 2, 3 months old and at the time of birth, respectively, and it decreased by 5.44 and $9.20 \%$ in the fetuses of 2.5 and 3.5 months old, respectively. The relative area of the parenchyma by 1.5 months old embryos is $36.97 \pm 0.93 \%$, it decreases by $4.06 \%$ in 2 months, it increases by $12.96 \%$ in 2.5 months, it decreases by $4.99 \%$ and $0.62 \%$ in accordance and it decreases by $3.21 \%$ in 4 months' embryos. The relative area of the myeloid tissue in 1.5 months old embryos is $52.32 \pm 0.93 \%$, it decreases by $2.58 \%$ in 2 months, by $13.94 \%$ in 2.5 months, in 3 months old embryos it decreases by $6.63 \%$, in 3.5 months by $9.68 \%$ and maximally decreases by $9.10 \%$ in 4 months.

The bone marrow is defined in the centre of the ossification of the skeleton at the beginning only of the fetal period of ontogenesis. Herewith the large majority of the quantity of the bone marrow is concentrated in the main centre of the ossification of the axial skeleton. So, a body height and a development of the relative area of the bone marrow in the main centre of the ossification in the 1.5 months old embryos of Sus scrofa domestica has got the close positive association with a development of a relative area of the bone tissue and the negative one with a cartilaginous tissue. While the relative area of the bone marrow in the main centre of the ossification in 1.5 months old embryos of Sus scrofa domestica, is approximately $1 / 2$ from the relative area of the bone marrow and the relative area of the cartilaginous tissue on the other way is more than 4-5 times as relative area of the bone marrow. During the fetal period of the ontogenesis by Sus scrofa domestica the relative area of the bone marrow increases against the decrease of the relative area of cartilaginous tissue, so during its first half (until 3 months) only because of development of the main in the unexceptionally all the bones of the axial skeleton and the skeleton of the extremities, and during the other half - the main and additional skeleton of the extremities.

It is found that the myeloid tissue of the parenchyma of the liver of Sus scrofa domestica by embryos in 1.5 months is shown mostly with hepatocytes and hemopoietic cells.

At the beginning of the fetal period of the ontogenesis, the relative area of hepatocytes in a liver a quite low and makes up $18.19 \pm 1.23 \%$, it increases until 4 months by about $41 \%$. The relative area of the hemopoietic cells by 1.5 months embryos is $77.45 \pm 3.91 \%$, and it decreases to the moment of birth for $40 \%$ (fig. 1).

The blood formation in the skeleton of the 1.5 months embryos takes place in the main centre of the ossification only, the additional centers of the ossification are not found out in the researched cells. The bone marrow in the centre 
of the ossification of the skeleton until the birth moment is shown with two structural-functional forms - osteoblastic (ossiferous) and red (bloodforming). It is characteristic that the bone marrow in the mostly of the main centre of the ossification of the skeleton of 1.5 months embryos is presented with both of its forms and in the main centre of the ossification of the caudal spines and the ramus of mandible with osteogenic only. In the area of the primary and secondary spongy bone substance of ramus of mandible, the 'eyelets' are formed with trabecules that are made from fibrous tissue, which are full of connective tissue (fig. 2).

The main cells of the osteoblastic bone marrow of 1.5 months Sus scrofa domestica em-

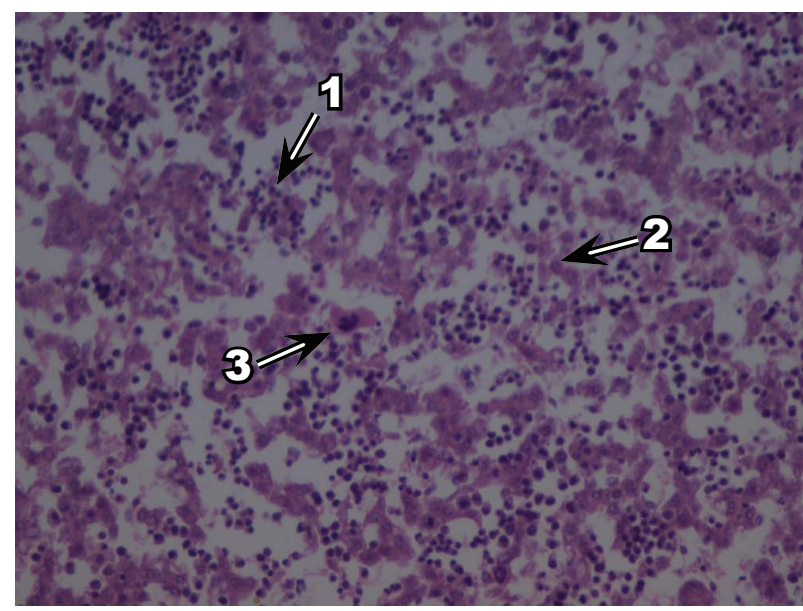

Fig. 1. The histospecimen of the liver of 1.5 months embryos of Sus scrofa domestica.

1 - hematopoietic cells; 2 - hepatocytes; 3 - megakaryocytes.

Coloured with hematoxylin and eosin. $\times 400$.

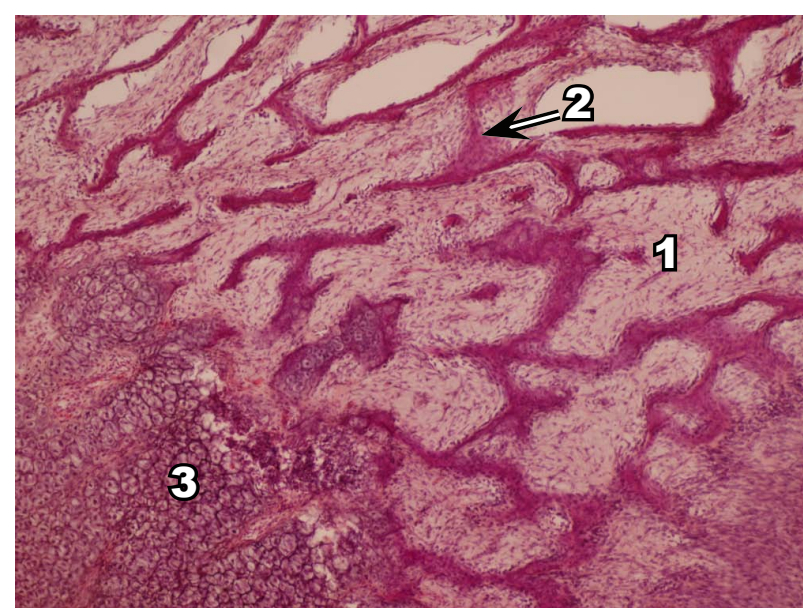

Fig. 2. The histospecimen of the ramus of mandible of 1.5 months embryos of Sus scrofa domestica.

1 - a cellular fibrous tissue; 2 - osteal trabecules; 3 - a cartilaginous tissue.

Coloured with hematoxylin and eosin. $\times 100$. bryos are the osteogenic ones; their relative area hesitates in the different of 1.5 months embryos from $80 \%$ to $85 \%$. The relative area of the stromal cells in the growing zone of the centers of the ossification of 1.5 months embryos is not more than 18-26\%. The extracellular structures of the osteoblastic bone marrow are presented with collagenous and reticular fiber. In a blood-forming bone marrow of 1.5 months embryos of Sus scrofa domestica the hemopoietic cells dominate from 15 to $55 \%$, which relative area increases in the central zones of centers of the ossification. It is characteristic that in the red bone marrow there are the osteogenic cells among the blood-forming ones, their relative area is much less than in the osteoblastic bone marrow and is not more than $25 \%$. The quantity of the stromal cells in the different centers of the ossification of the skeleton fluctuates from of $10-20 \%$.

The clearly marked zone structure of a bone marrow is characterized for 1.5 months embryos, which is kept in the mostly of the main centre of the ossification of the osteal organs until the birth time. During the other half of the fetal period of ontogenesis, there is clearly a pronounced transformation of red bone marrow from osteoblastic bone marrow due to intensive development of the hematopoietic elements of the bone marrow in areas of growth and their distribution in primary and secondary centers of ossification. Herewith there is an island structure of the bone marrow in the growing zones, and there is a diffusive island structure in the diaphyseal growing zones.

\section{Conclusions}

It is characteristic that the development of the red bone marrow in the main centre of the ossification of the skeleton of the embryos of Sus scrofa domestica accompanied with increase of a relative area in the zone of a secondary cancellous bone stock as a result of a decrease of the relative area of osteogenic cells in the growing zones.

Any of the fat cells appear in the bone marrow of the main centers of the ossification of the axial skeleton and the skeleton of extremities during all the fetal period. 
It has been stated that there are two basic structural end dynamic forms of bone brain and blood-making system during prenatal development. It has been obtained that from the moment of a 4 months old piglets have significant differences which consist in development area and type of structures of bone marrow, as clusters their separate particles.

It has been definite interrelation between erytro-, granulo- and megacariocytopoesis secondary mean- and large-cage spongial bone substance, and between developmental degrees of hemopoietic bone marrow according to system of microsurrounding with area of enchondral osteohistogenesis that was showed at indices of different clusters.

Perspectives for further research. Future studies will be aimed at identifying the structural and functional features of the universal organ of hematopoiesis and protective immunity in piglets in the early postnatal period of ontogenesis. Structural features will be installed in the bone shaft with hematopoietic microenvironment hematopoietic components of structure presents two main types - Islet diffused and liver - the restructuring of tissue and cell structures in the active period of training of the function of detoxification.

1. Alison M. R., Poulsom R., Forbes S. J. Update on hepatic stem cells. Liver, 2001, 21 (6), pp. 367-373.

2. Allen T. D. Haemopoietic microenvironments in vitro: ultrastructural aspects. Microenvironments in haemopoietic and lymphoid differentiation, 1981, pp. 38-67.

3. Chai B., Tang X., Li H. Osteoclastic resorbtion of Haversian systems in cortical bone of femoral neck in aged women. A scanning electron microscopic study. Chinese Medical Journal, 1996, vol. 109, no. 9, pp. 705-710.

4. Michurina T. V., Khrushchov N. G. Experimental analysis of cell interactions during haemopoiesis. Int. Journal Dev. Biol., 1997, vol. 41, pp. 817833. (in Russian)

5. Michurina T., Krasnov P., Balaz A., Nakaya N., Vasilieva T., Kuzin B., Khrushchov N. Nitric oxide is a regulator of hematopoietic stem cell activity. Mol. Therapy, 2004, vol. 10, no. 2, pp. 241-248. (in Russian)

6. Myrnyi O., Oliyar A. Morphogenesis haematopoietic components of the universal haematogenesis and immune protection of domestic pig's fetuses. Sciense and Technology Bulletin of Scientific research center for biosafety and environmental control of agroindustrial complex, 2014, vol. 2, no. 1, pp. 37-43. (in Ukrainian)

7. Parkman R. The biology of bone marrow transplantation for severe combined immunodeficiency. Adv. Immunol., 1991, vol. 49, pp. 381-388.

8. Peck W. A. Bone and mineral research. Amsterdam New York — Oxford: Elserier, 1989, pp. 338-410.

9. Taylor D., Dharmar M, Urquhart-ScottE, Ryan R. Relationship between pediatric blood and marrow transplant center volume and day +100 mortality: Pediatric Blood and Marrow Transplant Consortium experience. Bone Marrow Transplant, 2013, pp. 14-22.

10. Weiss L. The structure of bone marrow. Functional interrelation ships of vascular and hematopoietic compartments. An in experimental hemolytic anemia. An electron microscopic study. Journal Morphol., 1965, vol. 117 , no. 3 , pp. $467-537$. 